\title{
MOTYWY UCZESTNICTWA PRZYSZEYCH RODZICÓW W ZAJĘCIACH EDUKACYJNYCH SZKOŁY RODZENIA
}

\section{MOTIVES OF PARTICIPATION OF FUTURE PARENTS IN SCHOOL EDUCATION CLASSES BIRTH}

\author{
Wioletta Gębicz ${ }^{1, a}$, Katarzyna Plagens-Rotman ${ }^{2, b}$, Agnieszka Ulatowska ${ }^{3, c}$ \\ ${ }^{1}$ Wielospecjalistyczny Szpital Wojewódzki w Gorzowie Wielkopolskim \\ ${ }^{2}$ Katedra Zdrowia Matki i Dziecka, Uniwersytet Medyczny im. Karola Marcinkowskiego w Poznaniu \\ ${ }^{3}$ Zakład Praktyki Pielęgniarskiej, Uniwersytet Medyczny im. Karola Marcinkowskiego w Poznaniu \\ ${ }^{a}$ https://orcid.org/0000-0003-4348-8803 \\ ${ }^{\mathrm{b}} \mathrm{https}: / /$ orcid.org/0000-0001-7646-7430 \\ ${ }^{c}$ https://orcid.org/0000-0003-1698-6081
}

DOI: https://doi.org/10.20883/pielpol.2019.32

\section{STRESZCZENIE}

Wstęp. Szkoły rodzenia to placówki edukacyjne, które funkcjonują przy szpitalach lub innych ośrodkach medycznych prowadzące zajęcia teoretyczne oraz warsztaty praktyczne, mające na celu przygotowanie przyszłych rodziców do narodzin. Głównym zadaniem szkoły rodzenia jest zmniejszenie lęku porodowego poprzez właściwe przygotowanie obojga rodziców do porodu, jak również zdobycie wiedzy dotyczacej opieki nad dzieckiem po porodzie. Cel. Celem pracy było poznanie motywów uczestnictwa przyszłych rodziców w zajęciach edukacyjnych Szkoły Rodzenia. Materiał i metody. Badania przeprowadzono wśród uczestników kursu obojga płci w Szkole Rodzenia przy Wielospecjalistycznym Szpitalu Wojewódzkim w Gorzowie Wlkp. Badaniem objęto 200 słuchaczy biorących udział w wyżej wymienionej Szkole Rodzenia w okresie od stycznia do czerwca 2017 roku. W pracy zastosowano metodę sondażu diagnostycznego, badawczym narzędziem był kwestionariusz ankiety własnego projektu.

Wyniki. Najczęstszym źródłem wiedzy u osób w wieku między 23. a 27. roku życia był lekarz $(48,2 \%)$ oraz Internet $(35,7 \%)$, u osób w wieku między 28. a 32. roku życia były osoby znajome (71\%) oraz położna (21\%). Z kolei u osób w wieku między 33. a 38. roku życia główne źródło wiedzy o szkole rodzenia stanowił lekarz (95\%). Motywacją do uczestnictwa w zajęciach prowadzonych przez Szkołę Rodzenia wśród wieloródek było przygotowanie fizyczne i psychiczne do aktywnego porodu (75\%) oraz przygotowanie do pełnienia ról rodzicielskich (25\%). Z kolei główną motywacją do uczestnictwa w zajęciach Szkoły Rodzenia wśród kobiet oczekujących na pierwsze dziecko było przygotowanie do aktywnego porodu $(32,86 \%)$, zdobycie wiedzy w sprawowaniu opieki nad dzieckiem $(21,43 \%)$, pozyskanie wiedzy na temat ciąży (19,29\%) oraz udział w porodzie rodzinnym (16,43\%).

Wnioski. Należy dążyć do świadomego uczestnictwa kobiet ciężarnych w ćwiczeniach gimnastycznych, relaksacyjnych i oddechowych, które sprzyjają poprawie kondycji i wzmacniają postawy prozdrowotne. Zadaniem nadrzędnym edukacji przedporodowej jest kształtowanie postaw dążących do integracji obojga rodziców w zdobywaniu wiedzy o ciąży, porodzie, połogu i opieki nad dzieckiem poprzez przygotowanie psychiczne i fizyczne do aktywnego porodu.

SŁOWA KLUCZOWE: szkoła rodzenia, ciąża, poród, macierzyństwo, ojcostwo.

\section{ABSTRACT}

Introduction. Birth schools are educational institutions located at the hospitals or in other medical centers which organize parental education and childbirth classes aimed at preparing future parents to the birth of their child. The main task of birth school is to reduce labor fear by proper preparation of both parents for delivery, as well as gaining knowledge as part of the child's care after childbirth. Aim. The aim of the thesis is to determine the motives of expectant parents to participate in childbirth classes of a birth school. Material and methods. The study was carried out on both male and female participants of the School of Birth at the Multi-speciality Provincial Hospital in Gorzów Wielkopolski (Wielospecjalistyczny Szpital Wojewódzki w Gorzowie Wielkopolskim). The research involved 200 participants attending a training course of the Birth School between January and June 2017. Diagnostic survey was applied in the study and the research tool was an enquiry questionnaire form of the researcher's own design.

Results. The most common source of information for the future parents aged between 23 and 27 was a physician (48.2\%) and the Internet $(35.7 \%)$ and for the participants aged between 28 and 32 - acquaintances $(71 \%)$ and a midwife (21\%). The main source of information about the birth school for people aged between 33 and 38 was a physician (95\%). The motivation for participation in the classes conducted by the Birth School for multiparous women was physical and mental preparation to active delivery $(75 \%)$ and preparation to the role of a parent $(25 \%)$. The main motivation for the participation in the Birth School classes in women expecting the first child was preparation for an active delivery (32.86\%), gaining knowledge about childcare (21.43\%), acquiring knowledge about pregnancy (19, 29\%) and participation in a family birth (16.43\%).

Conclusions. The aware participation of pregnant women in gymnastic, relaxation and breathing exercises is advisable, as it improves the condition and strengthens the pro-health attitude of participants. The primary task of the prenatal education is to shape attitudes aiming at the integration of both parents in acquiring knowledge about pregnancy, labor, confinement and infant care through psychological and physical preparation to active labor.

KEYWORDS: a birth school, pregnancy, labor, motherhood, fatherhood. 


\section{Wstęp}

„Nowoczesne” Szkoły Rodzenia prowadzone przez wykwalifikowane położne, przy współpracy lekarzy położników i neonatologów, jak również psychologów i fizjoterapeutów powstają jako wyjście naprzeciw oczekiwaniom przyszłych rodziców.

Współcześnie uczestnictwo w zajęciach Szkoły Rodzenia wpisało się do kanonu poprawnego przygotowania do pełnienia ról rodzicielskich zarówno macierzyńskich, jak i ojcowskich. Coraz więcej par wykazuje zainteresowanie, aby ten piękny moment narodzin dziecka przeżywać wspólnie. Kobieta rodząca, przygotowana do porodu przez specjalistyczny zespół, uczestniczy w porodzie czynnie, podejmując zamierzone intencjonalne działania.

Współczesne Szkoły Rodzenia umożliwiają przyszłym rodzicom poznanie samych siebie w kontekście zadań i powinności związanych z ciążą, porodem i okresem poporodowym. Przyszli rodzice korzystający z zajęć mogą poznać behawioralne zachowania ukierunkowane na aktywny poród, odczytać swoje oczekiwania względem siebie oraz zdobyć umiejętności pielęgnacji dziecka i dopełnienia wobec niego obowiązków opiekuńczych. Partycypacja w kursach przedporodowych pomaga pozbyć się stereotypów, mitów i obaw związanych z ciążą i porodem. Przyszli rodzice otrzymują wiedzę i pewność siebie, które sprawią, że narodziny dziecka będą wzniosłym momentem dla obojga.

Niewątpliwą korzyścią dla rodziców jest możliwość uczestniczenia w swoistych grupach wsparcia podczas regularnych spotkań na zajęciach. Wspólne konsultacje, porównywanie odczuć, obaw daje możliwość poczucia więzi, poprawę nastroju i dodaje pewności siebie.

Formy zajęć proponowane przez polskie Szkoły Rodzenia podlegają ciągłym transformacjom, co wynika ze zmian, jakie dokonują się w polskim położnictwie.

\section{Cel}

Celem pracy było poznanie motywów uczestnictwa przyszłych rodziców w zajęciach edukacyjnych Szkoły Rodzenia.

\section{Materiał i metody}

W pracy zastosowano metodę sondażu diagnostycznego, natomiast badawczym narzędziem był kwestionariusz ankiety własnego projektu.

Badania przeprowadzono wśród uczestników kursu obojga płci w Szkole Rodzenia przy Wielospecjalistycznym Szpitalu Wojewódzkim w Gorzowie Wlkp. Udział osób w badaniach był anonimowy i dobrowolny. Badaniem objęto 200 słuchaczy biorących udział w wyżej wymienionej Szkole Rodzenia w okresie od stycznia do czerwca 2017 roku. Kurs przedporodowy obejmował 7 spotkań tematycznych podzielonych na trzy moduły:

1) moduł merytoryczny,

2) moduł praktyczny,

3) moduł aktywności fizycznej dla kobiet ciężarnych. Szczegółowy program Szkoły Rodzenia.

I. Spotkanie - higiena ciąży:

- ciąża o przebiegu prawidłowym i patologicznym,

- czynniki ryzyka w ciąży,

- zachowania prozdrowotne w czasie ciąży,

- elementy psychoprofilaktyki płodowej.

II. Spotkanie - fizjologia porodu:

- przebieg porodu fizjologicznego,

- poród aktywny,

- metody zmniejszania bólu porodowego,

- psychologiczne aspekty porodu,

- udział osoby towarzyszącej w porodzie,

- poród zabiegowy, operacyjny.

III. Spotkanie - adaptacja noworodka:

- komunikacja rodziców z dzieckiem po porodzie,

- pierwsze chwile życia noworodka,

- stany adaptacyjne,

- potrzeby psychofizyczne noworodka,

- szczepienia ochronne.

IV. Spotkanie - pielęgnacja i kąpiel noworodka:

- pierwszy rok życia dziecka „Kroki milowe”,

- przygotowanie domu i wyprawki dla dziecka,

- nauka umiejętności pielęgnacji noworodka,

- kąpiel noworodka.

V. Spotkanie - sposoby żywienia noworodka:

- karmienie naturalne,

- prezentacja pozycji i technik karmienia naturalnego,

- zasygnalizowanie problemów laktacyjnych sposoby wsparcia,

- dieta mamy karmiącej.

VI. Spotkanie - fizjologia połogu:

- poznanie zmian zachodzących w organizmie kobiety,

- pielęgnacja i higiena,

- rozwiązywanie problemów natury fizycznej i psychicznej - sposoby radzenia,

- opieka środowiskowa położna, ginekolog.

VII. Spotkanie - poznanie topografii oddziału położniczego, wejście na oddział.

Spotkania przedporodowe prowadzone były przez osoby posiadające kwalifikacje $w$ danej dziedzinie, tj.: położną, ginekologa, neonatologa, psychologa, pedagoga i fizjoterapeutę. W ramach spotkań odbywały się również warsztaty z pierwszej pomocy w stanach nagłych prowadzonych przez ratowników medycznych. 
W badaniach dokonano analizy statystycznej posługując się programem Statstica StatSoft Polska w wersji 12.5. Aby wykazać istniejące zależności statystyczne badanych zmiennych użyto testu chi-kwadrat Pearsona. W niniejszych badaniach przyjęto poziom istotności statystycznej $\alpha=0,05$. Wyniki interpretowano, jako istotne statystycznie, gdy wartość współczynnika wynosiła $\mathrm{p}<0,05$.

\section{Wyniki}

Badanie ankietowe przeprowadzono na grupie 200 osób w wieku 23-38 lat, z czego 76\% stanowiły kobiety, a 24\% mężczyźni. Większość respondentów mieszkało w mieście (94\%). 82\% ogółu posiadało wykształcenie wyższe, a 18\% średnie. Pozostałe dane socjodemograficzne przedstawiono w tabeli 1.

Tabela 1. Dane socjodemograficzne ankietowanych Table 1. Socio-demographic data of respondents

\begin{tabular}{|c|c|c|c|}
\hline \multicolumn{4}{|c|}{ Dane socjodemograficzne/Socio-demographic data } \\
\hline \multicolumn{2}{|c|}{ Parametr/Parameter } & \multirow{2}{*}{$\frac{N}{56}$} & \multirow{2}{*}{$\frac{\%}{28}$} \\
\hline \multirow{3}{*}{$\begin{array}{l}\text { Wiek (w latach)/ } \\
\text { age in years }\end{array}$} & $23-27$ & & \\
\hline & $28-32$ & 124 & 62 \\
\hline & $33-38$ & 20 & 10 \\
\hline \multirow{2}{*}{$\begin{array}{l}\text { Miejsce zamieszkania/ } \\
\text { place of residence }\end{array}$} & Miasto/city & 188 & 94 \\
\hline & Wieś/village & 12 & 6 \\
\hline \multirow{4}{*}{$\begin{array}{l}\text { Wykształcenie/ } \\
\text { education }\end{array}$} & Podstawowe/elementary & 0 & 0 \\
\hline & Zawodowe/vocational & 0 & 0 \\
\hline & Średnie/secondary & 36 & 18 \\
\hline & Wyższe/higher & 164 & 82 \\
\hline \multirow{2}{*}{$\begin{array}{l}\text { llość porodów/ } \\
\text { Number of births }\end{array}$} & Pierworódki/primiparas & 140 & 92 \\
\hline & Wieloródki/multiparas & 12 & 8 \\
\hline
\end{tabular}

Źródło: opracowanie własne

Source: author's own analysis

Na pytanie: „Co dla Pana/Pani oznacza nazwa Szkoła Rodzenia?”, respondenci w sposób różnorodny określali desygnat nazwy Szkoły Rodzenia. Ich odpowiedzi przedstawiono w tabeli 2 (panie) i tabeli 3 (panowie).

Tabela 2. Co dla Pana oznacza nazwa Szkoła Rodzenia? Table 2. What does the name 'birth school' mean to you?

\begin{tabular}{|c|c|c|c|}
\hline Lp. & $\begin{array}{c}\text { Co oznacza nazwa } \\
\text { Szkoła Rodzenia?/ } \\
\text { What does the name } \\
\text { 'birth school' mean } \\
\text { to you? }\end{array}$ & $\begin{array}{l}\text { Ogólna liczba } \\
\text { respondentów/ } \\
\text { Total number } \\
\text { of respondents }\end{array}$ & $\begin{array}{c}\text { Procent } \\
\text { respondentów/ } \\
\text { Percentage } \\
\text { of respondents }\end{array}$ \\
\hline
\end{tabular}

1. Bank wiedzy o ciąży, porodzie i opiece na dzieckiem/Knowledge 13

\begin{tabular}{|c|c|c|c|}
\hline 2. & $\begin{array}{l}\text { Przygotowanie do } \\
\text { ojcostwa/Preparation } \\
\text { for fatherhood, }\end{array}$ & 10 & 20 \\
\hline 3. & $\begin{array}{l}\text { Wskazówki, jak za- } \\
\text { chować się w czasie } \\
\text { porodu/Tips on how to } \\
\text { behave during delivery, }\end{array}$ & 8 & 17 \\
\hline 4. & $\begin{array}{l}\text { Poznanie oczekiwań } \\
\text { rodzącej podczas } \\
\text { porodu/Understanding } \\
\text { the expectations of the } \\
\text { birther during labor }\end{array}$ & 6 & 13 \\
\hline 5. & $\begin{array}{l}\text { Szkoła dla taty i mamy/ } \\
\text { School for a dad and } \\
\text { a mom }\end{array}$ & 5 & 10 \\
\hline 6. & $\begin{array}{l}\text { Opieka nad dzieckiem, } \\
\text { pielęgnacja/Infant care, } \\
\text { child care }\end{array}$ & 4 & 8 \\
\hline 7. & $\begin{array}{l}\text { Wiadomości o ciąży } \\
\text { porodzie i połogu/Infor- } \\
\text { mation about pregnan- } \\
\text { cy and confinement. }\end{array}$ & 2 & 4 \\
\hline
\end{tabular}

Źródło: Badania własne

Source: author's own analysis

Tabela 3. Co dla Pani oznacza nazwa Szkoła Rodzenia? Table 3. What does the name 'birth school' mean to you?

\begin{tabular}{|c|c|c|c|}
\hline Lp. & $\begin{array}{l}\text { Co oznacza nazwa Szkoła } \\
\text { Rodzenia?/ } \\
\text { What does the name 'birth } \\
\text { school' mean to you? }\end{array}$ & $\begin{array}{l}\text { Ogólna liczba } \\
\text { respondentów/ } \\
\text { Total number } \\
\text { of respondents }\end{array}$ & $\begin{array}{l}\text { Procent } \\
\text { respondentów/ } \\
\text { Percentage } \\
\text { of respondents }\end{array}$ \\
\hline 1. & $\begin{array}{l}\text { Przygotowanie do porodu } \\
\text { i przyjścia dziecka w rodzinie/ } \\
\text { Preparation for delivery and the } \\
\text { birth of a child in a family }\end{array}$ & 43 & 28 \\
\hline 2. & $\begin{array}{l}\text { Opieka nad noworodkiem, pielę- } \\
\text { gnacja i żywienie/Care for } \\
\text { a newborn, nutrition }\end{array}$ & 40 & 26 \\
\hline 3. & $\begin{array}{l}\text { Szkoła dla mamy i taty/A school } \\
\text { for a mom and a dad }\end{array}$ & 24 & 16 \\
\hline 4. & $\begin{array}{l}\text { Źródło wiedzy o porodzie/The so- } \\
\text { urce of knowledge about the labor }\end{array}$ & 15 & 10 \\
\hline 5. & $\begin{array}{l}\text { Przygotowanie psychiczne } \\
\text { i fizyczne do porodu/ Psycholo- } \\
\text { gical and physical preparation } \\
\text { for the labor }\end{array}$ & 12 & 8 \\
\hline 6. & $\begin{array}{l}\text { Przygotowanie do macierzyń- } \\
\text { stwa, rodzicielstwa/ Preparation } \\
\text { for motherhood, parenthood }\end{array}$ & 9 & 6 \\
\hline 7. & $\begin{array}{l}\text { Merytoryczna wiedza o ciąży, } \\
\text { porodzie i połogu/ Substantial } \\
\text { knowledge about pregnancy, } \\
\text { labor and confinement }\end{array}$ & 9 & 6 \\
\hline
\end{tabular}

Źródło: opracowanie własne

Source: author's own analysis

Motywami uczestnictwa dla panów w zajęciach edukacyjnych Szkoły Rodzenia na pierwszym miejscu było przygotowanie do udziału w porodzie rodzinnym, 
tj. 33\% ankietowanych. W dalszej kolejności kierowali się zdobyciem wiedzy na temat opieki nad dzieckiem - 28\%. Natomiast głównym motywem uczestnictwa w zajęciach edukacyjnych Szkoły Rodzenia wśród pań było przygotowanie do aktywnego porodu zarówno w płaszczyźnie fizycznej, jak i psychicznej - 36\% ankietowanych. Dane liczbowe i procentowe przedstawiono w tabeli 4.

Tabela 4. Motywy uczestnictwa w Szkole Rodzenia Table 4. Motivation for participation in the birth school

\begin{tabular}{|c|c|c|c|c|c|}
\hline Lp. & $\begin{array}{c}\text { Motywy } \\
\text { uczestnictwa } \\
\text { w Szkole } \\
\text { Rodzenia/ } \\
\text { Motivation for } \\
\text { participation in } \\
\text { the birth school }\end{array}$ & $\begin{array}{l}\text { Liczba } \\
\text { mężczyzn/ } \\
\text { number } \\
\text { of men }\end{array}$ & $\begin{array}{l}\text { Ogólna liczba } \\
\text { / respondentów/ } \\
\text { Total number } \\
\text { of respondents }\end{array}$ & $\begin{array}{l}\text { Liczba } \\
\text { kobiet/ } \\
\text { number } \\
\text { of women }\end{array}$ & $\begin{array}{l}\text { Ogólna liczba } \\
\text { respondentów/ } \\
\text { Total number } \\
\text { of respondents }\end{array}$ \\
\hline & $\begin{array}{l}\text { Pozyskanie } \\
\text { wiedzy na temat } \\
\text { ciąży/Acquiring } \\
\text { knowledge about } \\
\text { pregnancy }\end{array}$ & 9 & $19 \%$ & 27 & $18 \%$ \\
\hline & $\begin{array}{l}\text { Przygotowanie } \\
\text { do aktywnego } \\
\text { porodu: psy- } \\
\text { chiczne i fizycz- } \\
\text { ne/ Both mental } \\
\text { and physical } \\
\text { preparation for } \\
\text { an active labor }\end{array}$ & 0 & $0 \%$ & 55 & $36 \%$ \\
\hline & $\begin{array}{l}\text { Udział w poro- } \\
\text { dzie rodzinnym/ } \\
\text { Participation } \\
\text { in a family birth }\end{array}$ & 16 & $33 \%$ & 23 & $15 \%$ \\
\hline & $\begin{array}{l}\text { Zdobycie wiedzy } \\
\text { w sprawowaniu } \\
\text { opieki nad dziec- } \\
\text { kiem/Gaining } \\
\text { knowledge about } \\
\text { taking care } \\
\text { of a child }\end{array}$ & $t$ & $28 \%$ & 30 & $20 \%$ \\
\hline & $\begin{array}{l}\text { Przygotowanie } \\
\text { do pełnienia ról } \\
\text { rodzicielskich/ } \\
\text { Preparation for } \\
\text { parental roles }\end{array}$ & 10 & $20 \%$ & 17 & $11 \%$ \\
\hline
\end{tabular}

Źródło: opracowanie własne

Source: author's own analysis

Wyniki ankiety potwierdziły, że Szkoła Rodzenia realizująca zajęcia zgodne z ustalonym programem edukacyjnym spełniła oczekiwania przyszłych rodziców, pozwalając im na zdobycie wiedzy i umiejętności z zakresu ciąży, porodu i połogu (100\% ankietowanych).

Najczęstszym źródłem wiedzy u osób w wieku między 23. a 27. rokiem życia był lekarz $(48,2 \%)$ oraz Internet $(35,7 \%)$. U osób w wieku między 28 . a 32. rokiem życia najczęstszym źródłem wiedzy były osoby znajome $(71 \%)$ oraz położna (21\%), z kolei u osób w wieku między 33. a 38. r.ż. główne źródło wiedzy o szkole rodzenia stanowił lekarz (95\%). Różnice między grupami były istotne statystycznie ( $p<0,001)$.

$\mathrm{Na}$ pytanie dotyczące motywacji do uczestnictwa w zajęciach edukacyjnych Szkoły Rodzenia odpowiedzi były następujące. W grupie wiekowej między 23 . a 27. r.ż. najczęstszą motywacją było zdobycie wiedzy na temat sprawowania opieki nad dzieckiem $(69,6 \%)$ oraz przygotowanie do pełnienia ról rodzicielskich (25\%), natomiast w grupie wiekowej między 28. a 32. rokiem życia było przygotowanie do aktywnego porodu psychicznie i fizycznie (34,7\%) oraz udział w porodzie rodzinnym $(28,2 \%),(p<0,001)$. Dane przedstawiono na rycinie 1.

Zarówno w grupie wiekowej między 23. a 27. rokiem życia oraz grupie wiekowej między 33. a 38. rokiem życia zajęcia prowadzone w szkole rodzenia zmniejszyły obawy związane z przebiegiem ciąży, porodu i połogu (100\%). Z kolei w grupie wiekowej między 28. a 32. r.ż. prowadzone zajęcia pomogły w podjęciu decyzji o porodzie rodzinnym $(39,5 \%),(p<0,001)$.

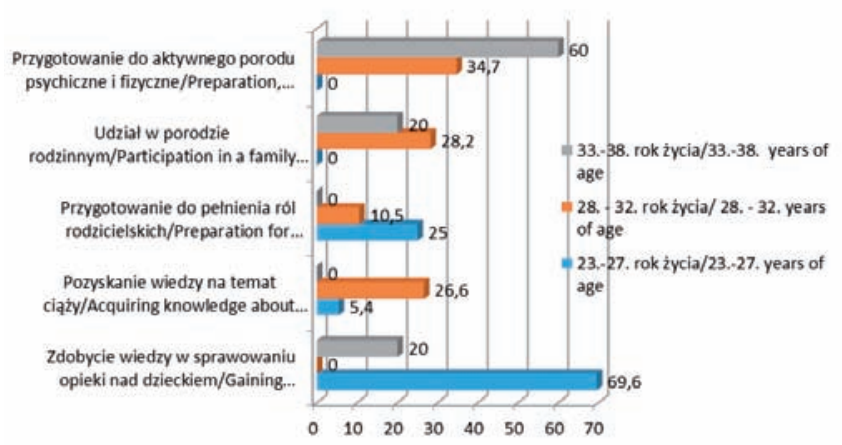

Rycina 1. Jaka była motywacja do uczestnictwa w zajęciach edukacyjnych Szkoły Rodzenia? Odpowiedzi z podziałem badanych osób na przedziały wiekowe

Figure 1. What was the motivation to participate in the educational activities of the Birth School? Answers with the division of respondents into age groups.

Źródło: opracowanie własne

Source: author's own analysis

Najczęstszym źródłem wiedzy o szkole rodzenia wśród badanych osób względem miejsca zamieszkania były: osoby znajome (46\% osoby mieszkające w mieście vs $45,5 \%$ osoby mieszkające na wsi), lekarz (27,3\% osoby mieszkające na wsi vs $24,9 \%$ osoby mieszkające w mieście), czasopisma (18,2\% osoby mieszkające we wsi vs $5,3 \%$ osoby mieszkające w mieście), oraz Internet $(10,1 \%$ osoby mieszkające w mieście vs $9,1 \%$ osoby 
mieszkające na wsi). Dane były nieistotne statystycznie $(p>0,05)$. Dane przedstawiono na rycinie 2.

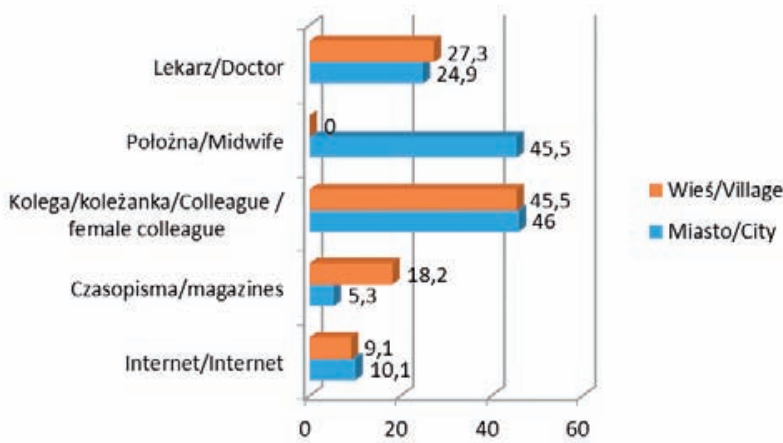

Rycina 2. Skąd Pan/Pani dowiedział/a się o Szkole Rodzenia? Odpowiedzi z podziałem badanych osób na miejsce zamieszkania

Figure 2. Where did you find out about the School of Birth? Answers with the division of respondents to their place of residence

Źródło: opracowanie własne

Source: author's own analysis

Najczęstszą motywacją badanych osób było psychiczne oraz fizyczne przygotowanie do aktywnego porodu $(45,5 \%$ osób mieszkający na wsi vs $26,5 \%$ osób mieszkających w mieście). Częstą udzielaną odpowiedzią była chęć udziału w porodzie rodzinnym (27,3\% osób mieszkający na wsi vs $19,1 \%$ osób mieszkających w mieście), a także zdobywanie wiedzy o sprawowaniu opieki nad dzieckiem (21,7\% osób mieszkających w mieście vs $18,2 \%$ osób mieszkających we wsi). Nie wykazano istotnej statystycznie różnicy w udzielonych odpowiedziach przez grupę osób zamieszkującą miasto oraz wieś ( $p>0,05)$, rycina 3. Różnice nie były istotne statystycznie.

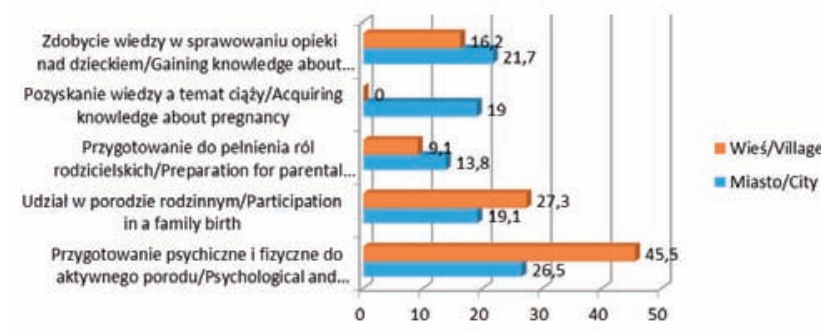

Rycina 3. Jaka była motywacja do uczestnictwa w zajęciach edukacyjnych Szkoły Rodzenia? Odpowiedzi z podziałem badanych osób na miejsce zamieszkania

Figure 3. What was the motivation to participate in the educational activities of the School of Birth? Answers with the division of respondents to their place of residence

Źródło: opracowanie własne Source: author's own analysis
Zajęcia prowadzone przez szkołę rodzenia zmniejszały u badanych osób obawy związane z przebiegiem ciąży, porodu i połogu (63,6\% osób mieszkających na wsi oraz $57,1 \%$ osób mieszkających w mieście), a także pomagały podjać decyzję o uczestnictwie w porodzie rodzinnym (36,4\% osób mieszkających na wsi w porównaniu do $23,8 \%$ osób mieszkających w mieście), $(p>0,05)$. Dane przedstawiono na rycinie 4.

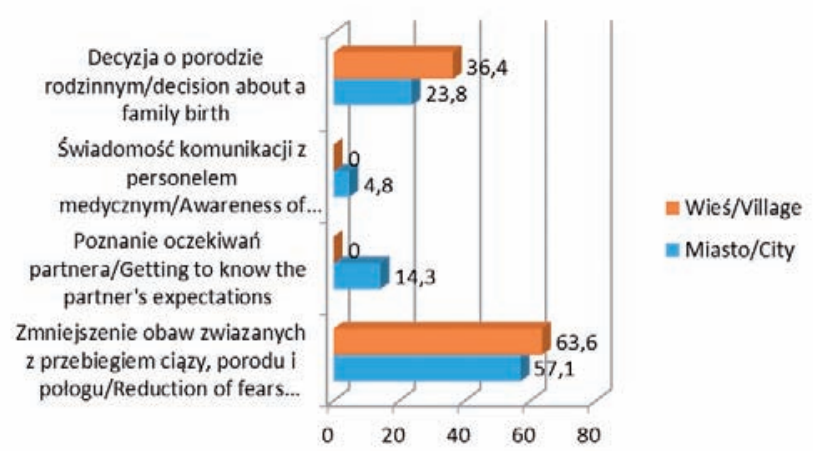

Rycina 4. Jaką rolę odegrało uczestnictwo Pana/Pani w zajęciach edukacyjnych Szkoły Rodzenia? Odpowiedzi z podziałem badanych osób na miejsce zamieszkania

Figure 4. What role did your participation in the Learning School's educational activities play? Answers with the division of respondents to their place of residence

Źródło: opracowanie własne

Source: author's own analysis

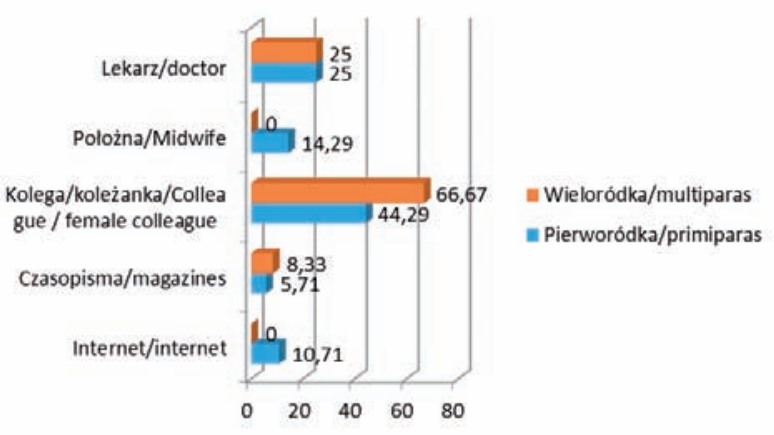

Rycina 5. Skąd Pan/Pani dowiedział/a się o Szkole Rodzenia? Odpowiedzi z podziałem badanych kobiet na pierworódki oraz wieloródki Rycina 5. How did you find out about the School of Birth? Answers with the division of women surveyed into primiparas and multiparas

Źródło: opracowanie własne

Source: author's own analysis

Analizowanie źródła wiedzy o Szkole Rodzenia wśród pierworódek oraz wieloródek dało wynik: oso- 
by znajome, odpowiednio $44,29 \%$ vs $66,67 \%$, lekarz (25\% pierworódki oraz wieloródki). Jako źródło wiedzy pierworódki podawały Internet $(10,71 \%)$ oraz położną $(14,29 \%)$, wieloródki natomiast czasopisma (8,33\% vs $5,71 \%)$. Brak istotności statystycznej $(p>0,05)$. Dane przedstawiono na rycinie 5.

Główną motywacją do uczestnictwa w zajęciach prowadzonych przez Szkołę Rodzenia wśród wieloródek było głównie przygotowanie fizyczne i psychiczne do aktywnego porodu (75\% wieloródek) oraz przygotowanie do pełnienia ról rodzicielskich ( $25 \%$ wieloródek). Z kolei główną motywacją do uczestnictwa w zajęciach Szkoły Rodzenia wśród kobiet oczekujących na pierwsze dziecko było przygotowanie do aktywnego porodu (32,86\%), zdobycie wiedzy o sprawowaniu opieki nad dzieckiem (21,43\%), pozyskanie wiedzy na temat ciąży $(19,29 \%)$ oraz udział w porodzie rodzinnym $(16,43 \%)$, $(p=0,01)$. Dane przedstawiono na rycinie 6 .

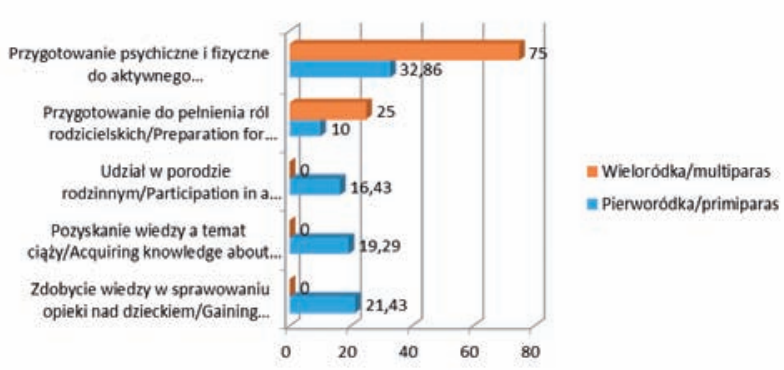

Rycina 6. Jaka była motywacja do uczestnictwa w zajęciach edukacyjnych Szkoły Rodzenia? Odpowiedzi z podziałem badanych kobiet na pierworódki oraz wieloródki

Rycina 6. What was the motivation to participate in the School of Birth educational activities? Answers with the division of women surveyed into primiparas and multiparas

Źródło: opracowanie własne

Source: author's own analysis

Zbadano również istniejące różnice w udzielanych przez pierwiastki oraz wieloródki odpowiedziach dotyczących roli odegranych przez zajęcia edukacyjne w szkole rodzenia. $61,43 \%$ pierwiastek w porównaniu do $41,67 \%$ wieloródek twierdzi, że zajęcia zmniejszyły obawy związane z przebiegiem ciąży, porodu i połogu. Natomiast tylko 24,29\% pierwiastek w porównaniu do 58,33\% wieloródek twierdzi, iż zajęcia w szkole rodzenia pomogły w podjęciu decyzji o uczestnictwie w porodzie rodzinnym, $(p>0,05)$. Dane przedstawiono na rycinie 7.

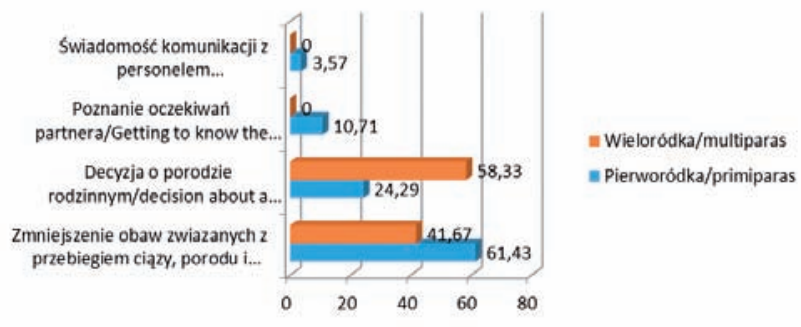

Rycina 7. Jaką rolę odegrało uczestnictwo w zajęciach edukacyjnych Szkoły Rodzenia? Odpowiedzi z podziałem badanych kobiet na pierworódki oraz wieloródki

Rycina 7. What role did participation in the School of Birth educational activities play? Answers with the division of women surveyed into primiparas and multiparas

Źródło: opracowanie własne

Source: author's own analysis

\section{Dyskusja}

Rozwój psychoprofilaktyki w Polsce został zapoczątkowany w połowie lat pięćdziesiątych XX wieku przez pioniera tego kierunku prof. J. Lesińskiego. Fijałkowski, jako inicjator ruchu porodu naturalnego, otrzymał przydomek „Ojca” polskich szkół rodzenia [1]. Głównym pozytywem koncepcji Fijałkowskiego była edukacja kompleksowa, psychoprofilaktyczna i kinezyadaptacyjna [2]. Projekt psychofizyczny modelował sposób myślenia i przygotowania kobiety oczekującej na narodziny dziecka. Bauman wskazał, że współczesne kobiety zatraciły spontaniczne zachowania w naturalnym porodzie. Podkreśla znaczenie szerzenia wiedzy, która pozwoli odzyskać kobietom kontakt ze sferą naturalnego instynktu [3].

Projekt psychoprofilaktyki porodowej Fijałkowskiego zainicjował powstanie Szkół Rodzenia funkcjonujących jako placówki edukacyjne realizujące swoją działalność przy szpitalach lub innych ośrodkach medycznych. Szkoła Rodzenia oferuje zajęcia teoretyczne i praktyczne przygotowujące przyszłych rodziców do narodzin potomka. Wielu autorów określa ten zakres działania jako źródło miarodajnej wiedzy [4]. Psychoprofilaktyka porodu, jako metoda pracy, ma na celu zmniejszenie obaw i lęków w czasie porodu poprzez przyjęcie dynamicznej postawy przez oboje rodziców. Model psychofizyczny przygotowuje kobietę do narodzin oczekiwanego dziecka w kontekście konstruktywnego zadania. Obserwuje się, że coraz więcej par pragnie ten trudny, a zarazem piękny moment narodzin dziecka przeżywać wspólnie. Poród jako wydarzenie jest rozpoczęciem drogi na płaszczyźnie rodzicielskiej. Proces ten nazywany jest odkrywaniem ojcostwa i macierzyństwa. Przyszli rodzice razem podejmują nowe zadania, a co bardzo ważne, uczą się bezpośredniej komunikacji z dzieckiem. 
Reasumując, należy wskazać, że treści edukacyjne Szkół Rodzenia, obejmują wielokierunkowe przygotowanie rodziców z zakresu ciąży, porodu i opieki nad dzieckiem. W toku zajęć zostaje przedstawiony model rodziny, którego fundamentem jest wspólna odpowiedzialność i wzajemne uzupełnianie się partnerów w sprawowaniu ról opiekuńczo-pielęgnacyjnych i wychowawczych. Kryszk B. i wsp. nazywają taki stan „komplementarnym współrodzicielstwem" [3]. Janus i wsp. [5] podkreślają, że rodzina jako formacja jest dla społeczeństwa komórką, której najważniejszą funkcją jest przedłużenie istnienia w znaczeniu biologicznym i kulturowym.

Przeprowadzone badania w Szkole Rodzenia przy Wielospecjalistycznym Szpitalu Wojewódzkim w Gorzowie Wlkp. dowodzą o zainteresowaniu obu płci edukacją przedporodową. Ankietowani uczestnicy wykazali zainteresowanie zajęciami w Szkole Rodzenia, chęcią pozyskania wiedzy z zakresu ciąży, porodu i sprawowania opieki nad dzieckiem. Lisius i wsp. [6] w swoich analizach wskazują, że zaangażowanie rodziców w szkoleniach przedporodowych działa modyfikująco na poziom posiadanej wiedzy.

Badaniami objęto grupę kobiet pomiędzy 23. a 38 . roku życia, a mężczyzn pomiędzy 26. a 38. rokiem życia. Należy zauważyć, że wiek respondentów sprzyja zakładaniu rodzin i planowaniu wspólnego rodzicielstwa. Młodzi partnerzy wykazują gotowość, aby przyjąć nowe zadanie wynikające z decyzji o założeniu rodziny. Jednym z celów istnienia Szkół Rodzenia jest wpływ na kształtowanie nowego modelu rodziny, w którym macierzyństwo jest na równi z ojcostwem [4].

W naszych badaniach osoby najmłodsze znacznie częściej zdobywały wiedzę na temat szkoły rodzenia z Internetu, od lekarza oraz od osób znajomych, z kolei starsi rodzice dowiadywali się o zajęciach szkoły rodzenia wyłącznie od lekarza. Inne były także motywacje badanych osób uczestniczących w zajęciach szkoły rodzenia. Osoby młodsze znacznie częściej uczestniczyły w zajęciach szkoły rodzenia w celu zdobycia wiedzy w sprawowaniu opieki nad dzieckiem, z kolei główną motywacją starszych rodziców było przygotowanie psychiczne i fizyczne do aktywnego porodu. Kwak zaznacza, że młodzi rodzice muszą zaakceptować nową sytuację, a wzajemna komunikacja będzie kształtować ich relacje małżeńskie [7].

Analizując ilość porodów, w badaniach własnych 92\% kobiet określiło, że oczekuje pierwszego dziecka, a $8 \%$ wskazało, że będzie to drugie dziecko. Badania Żelazko. i wsp. [8] również wykazują, że 83\% kobiet uczestniczących w spotkaniach Szkoły Rodzenia to pierworódki. Zbliżone wyniki zaprezentował również Kołomyjec i wsp. [9], gdzie pierwiastki stanowiły 85\% badanych. W badaniach Szałkowskiego i wsp. [10] wy- kazano, że pierworódki wykazywały bardziej zróżnicowane oraz odmienne przyczyny motywacji w uczestnictwie w zajęciach prowadzonych przez Szkołę Rodzenia. Częstszą ich motywacją było zdobycie wiedzy w sprawowaniu opieki nad dzieckiem, pozyskanie wiedzy na temat ciąży oraz przygotowanie do aktywnego porodu. Wieloródki odpowiadały w sposób mniej zróżnicowany, a ich główną motywacją uczestnictwa w zajęciach było przygotowanie do aktywnego porodu psychicznie i fizycznie.

Badania własne potwierdzają, że liczebność kobiet w kolejnej ciąży na edukacyjnych spotkaniach przedporodowych jest mała, tylko $8 \%$ ankietowanych. Uzyskane wyniki potwierdzają, że dla wieloródek poród pierwszy jest empirycznie wystarczającym wydarzeniem, stąd mniejsza frekwencja na zajęciach w Szkole Rodzenia. Podobne wyniki uzyskali w swoich badaniach Spinelli i wsp. [11] oraz Fabian i wsp. [12].

Współczesne rodziny prezentują szeroki światopogląd i oczekują merytorycznej, wiążącej informacji z zakresu ciąży, porodu i zaspokajania potrzeb narodzonego dziecka. Równolegle wykazują dużą aktywność w dążeniu do świadomego udziału w akcie porodu oraz w długotrwałym procesie rozwoju swojego potomka. Taką postawę potwierdzili respondenci w naszych badaniach. Mężczyźni wskazali, że Szkoła Rodzenia to „bank wiedzy o ciąży, porodzie i opiece nad dzieckiem; przygotowanie do ojcostwa". Objęte badaniem kobiety opisały, że Szkoła Rodzenia to „przygotowanie do porodu i przyjścia na świat dziecka oraz przygotowanie do macierzyństwa”. Zarówno mężczyźni, jak i kobiety, określili Szkołę Rodzenia, jako „szkołę dla taty i mamy” bądź „szkołę dla mamy i taty”. Badania własne pozwoliły nam uzyskać indywidualne wypowiedzi ankietowanych kobiet:

„Szkoła rodzenia to czas takiego nauczenia się siebie i swoich możliwości, aby poród naturalny był rzeczą naturalną. Bezpieczny, pełen spokoju i wiary w swoje możliwości, będzie to jedna z najpiękniejszych chwil mojego życia."

„Szkoła rodzenia to dla mnie „coś” bardzo ważnego, coś, co pozwoli mi utożsamić się ze stanem, w którym się obecnie znajduję."

„Szkoła rodzenia to miejsce, gdzie istnieje możliwość uzyskania odpowiedzi na nurtujące mnie pytania."

„Szkoła rodzenia to czas edukacji w celu przygotowania się do „egzaminu”, jakim jest dla mnie poród.”

Deklaracje respondentek obrazują bardzo osobiste i pełne emocji wypowiedzi.

Jodłowska-Sowińska [13] w swoich badaniach potwierdza, że rodzice znają obszar edukacji Szkół Rodzenia i mają sprecyzowane oczekiwania. Nasze badania pokazały, że głównym motywem uczestnictwa 
przyszłych rodziców w zajęciach edukacyjnych Szkoły Rodzenia była chęć pozyskania wiedzy z zakresu ciąży, porodu i opieki nad dzieckiem. Zaprezentowane motywy w badaniach własnych pozwalają stwierdzić, że przyszli rodzice bardzo odpowiedzialnie i świadomie przygotowują się do macierzyństwa i ojcostwa. Uczestnicy zajęć podkreślili wage poznania wzajemnych potrzeb i oczekiwań partnerów w czasie ciąży, porodu i połogu. Stanowisko rodziców potwierdziło dążenie do wypracowania aktywnej i świadomej postawy w całym okresie okołoporodowym. Takie same motywy prezentują w swoich publikacjach Rochala [14] oraz Puszczałowska i wsp. [15]. Współmierne wyniki przedstawia w swoich badaniach Mazurkiewicz i wsp. [16]. Natomiast Ćwiek [17] podkreśla w swoich badaniach, że rodzice uczestniczący w zajęciach Szkoły Rodzenia przyjmują prozdrowotne zachowanie, które korzystnie wpływa na przebieg ciąży, porodu i połogu. Mazurkiewicz i wsp. [18] przedstawiają motywy ukierunkowane na poród rodzinny, który daje kobiecie poczucie bezpieczeństwa, wsparcie i możliwość bycia razem z osobą towarzyszącą podczas porodu. Według badań przeprowadzonych przez Modrzejewską i wsp. [19] potrzeba uczestnictwa przyszłych rodziców w zajęciach Szkoły Rodzenia przekłada się na wzmocnienie więzi rodzicielskich.

Równomiernie rozłożyły się wyniki badań, co do decyzji o porodzie rodzinnym, którą podjęto przed ciążą, w początkowym jej okresie lub po spotkaniach w Szkole Rodzenia. Większość, bo aż 44\% badanych, uważała, że ostateczną decyzję o porodzie rodzinnym podjęła po zajęciach edukacyjnych.

Respondenci ocenili pozytywnie grupowe spotkania w Szkole Rodzenia. Takie rozwiązania dają możliwość uczestniczenia rodziców w tzw. „grupach wsparcia” [19]. Podobne opinie w swoich badaniach publikuje Olejniczak i wsp. [20] oraz Wolbiś i wsp. [21] wskazując, że rola partnera w edukacji to ogromne wsparcie dla rodzącej. W naszych badaniach ankietowani rodzice potwierdzili, że spotkania w Szkole Rodzenia spełniły ich oczekiwania w wymiarze teoretycznym i praktycznym. Ponadto respondenci potwierdzają potrzebę działania Szkół Rodzenia jako placówek edukacyjnych. Zdaniem ankietowanych Szkoła Rodzenia w sposób pragmatyczny przyczyniła się do zmniejszenia obaw związanych z przebiegiem ciąży i porodu.

Takie argumenty w swoich badaniach prezentuje Żelazko i wsp. [22], że Szkoła Rodzenia spełniła oczekiwania zainteresowanych, a uczestnicy pozyskali wiedzę teoretyczna i praktyczną w badanym obszarze. Potwierdzenie, że wiedza z zakresu okołoporodowego jest bardzo potrzebna opisuje również w badaniach Kołomyjec i wsp. [23].
Kamińska i wsp. [24] podkreślają, że wszystkie uczestniczki zajęć w Szkole Rodzenia potwierdzały, że przygotowanie w ramach edukacji przedporodowej jest jak najbardziej słuszne. Badania własne potwierdzają, że uczestnicy zalecają wręcz przyszłym rodzinom odbycie kursu w Szkole Rodzenia. Taką opinię wyraziło $100 \%$ badanych. Kurs w Szkole Rodzenia wpłynął w sposób zasadniczy na akceptację sytuacji i dostosowanie się do nowych zadań, potwierdziło to 95\% badanych. Wszyscy badani podkreślili, iż treści przekazane podczas spotkań w Szkole Rodzenia były „wystarczające" i że poleciliby kurs w Szkole Rodzenia swoim znajomym.

Szkoły Rodzenia umożliwiają przyszłym rodzicom poznanie swoich zadań rodzicielskich oraz przygotowują do bezpiecznego przeżycia ciąży, porodu i opieki nad dzieckiem. Niewątpliwą korzyścią dla rodziców jest możliwość uczestniczenia w swoistych grupach wsparcia podczas regularnych spotkań w szkole rodzenia. Wspólne konsultacje, porównywanie odczuć czy obaw, daje możliwość poczucia więzi i dodaje pewności siebie. Każda kobieta, która jest w ciąży i spodziewa się dziecka, niezależnie, czy jest to pierwsze dziecko, czy kolejne, odczuwa wiele obaw nie tylko o swój stan zdrowia, ale przede wszystkim o stan zdrowia i życia dziecka. Szkoła Rodzenia przygotowuje przyszłych rodziców w sposób profesjonalny w płaszczyźnie psychicznej i fizycznej do ciąży, porodu i połogu oraz opieki nad dzieckiem. Programy edukacyjne realizowane w Szkole Rodzenia dają przyszłym rodzicom poczucie bezpieczeństwa, realizowane przez działania informacyjne i zachowania praktyczne.

Analiza badań własnych potwierdza, że istnieje ogromne zapotrzebowanie na edukację przedporodową. Wiedza prozdrowotna przekazywana na spotkaniach w Szkole Rodzenia kompensuje występowanie problemów dotyczących okresu ciąży, porodu i połogu oraz opieki nad dzieckiem. W. Fijałkowski w swoich publikacjach nawoływał, by podejmować wiążące działania, które upowszechnią Szkoły Rodzenia. Należy podejmować kroki sprzyjające tworzeniu nowych placówek edukacyjnych pod nazwą Szkoła Rodzenia.

\section{Wnioski}

1. Obecność partnerów na spotkaniach Szkoły Rodzenia potwierdziła dążenie do wypracowania aktywnej i świadomej postawy w akcie porodu.

2. Słuchacze kursu od Szkoły Rodzenia oczekują profesjonalnego przygotowania do okresu okołoporodowego.

3. Należy dążyć do świadomego uczestnictwa kobiet ciężarnych w ćwiczeniach gimnastycznych, 
relaksacyjnych i oddechowych, które sprzyjają poprawie kondycji i wzmacniają postawy prozdrowotne.

4. Należy uświadomić zainteresowanym, że najbardziej wiarygodnym źródłem informacji z dziedziny położnictwa jest położna i lekarz ginekolog.

\section{Piśmiennictwo}

1. Olejniczak D, Krakowiak K. Ocena potrzeby edukacji zdrowotnej kobiet $\mathrm{w}$ ciąży $\mathrm{w}$ zakresie stylu życia i karmienia piersią. Nowa Pediatria 2013; 3: 97-105.

2. Kormas-Biela D. Polski model psychoprofilaktyki porodowej według prof. W. Fijałkowskiego.

3. Kryszk B, Kaliwoda B, Sybilski AJ. Wpływ kształcenia w szkole rodzenia na postawy i zachowanie zdrowotne jej słuchaczy. Probl Lek. 2011; 47(1): 31-5.

4. Fijałkowski W. U progu rodzicielstwa. Wrocław 1992; 95-114.

5. Janus B, Zieliński J. Bezpieczne i szczęśliwe macierzyństwo. Pielęgniarka i Położna 1988; 12: 10.

6. Lisius E, Michalik A. Uczestnictwo w zajęciach Szkoły Rodzenia jako forma psychoprofilaktyki. Położna. Nauka i Praktyka 2008; 4: 48.

7. Kwak M. Opinie kobiet ciężarnych na temat wybranych aspektów organizacyjnych opieki położniczej. Pielęgniarstwo Polskie 2003; 1: 46-49.

8. Żelazko K, Szlączka A, Pałczyńska M, Jaros A. Ocena przygotowania ciężarnej do porodu i macierzyństwa przez Szkołę Rodzenia. Współczesne Pielęgniarstwa i Ochrona zdrowia 2016; 2: 52-55.

9. Kołomyjec P, Suchocki S, Kędra-Rakoczy M. Wykształcenie i zachowanie prozdrowotne ciężarnych biorących udział w zajęciach Szkoły Rodzenia oraz ich wpływ na przebieg porodu i stan noworodka 2007; 3: 57-60.

10. Szałkowski A, Cendrowski A, Jaskólska M. Analiza przebiegu i sposobu zakończenia porodu u pacjentek po kursie w Szkole Rodzenia. Klin. Perinatol. Ginek. 2002, 25: 201-207.

11. Spinelli A, Baglio G, Donati S, et al. Do antenatal classes benefit the mother and her baby? J. Mantern Fetal Neonatal Med 2003; 2: 94-101.

12. Fabian HM, Radestad J, Waldenström V. Characteristics of Swedish women who do not attend childbirth and parenthood education classes Turing pregnancy. Midwifery 2004; 3: 226-234.

13. Jodłowska-Sowińska M. Oczekiwania kobiet ciężarnych XXI wieku. Położne Nauka i Praktyka 2010; 1: 48-51.

14. Rochala KL. Motywacja rodziców do udziału w kursach Szkoły Rodzenia. Pielęgniarstwo XXI wieku 2008; 1: 10-18.
15. Puszczałowksa-Lizis E, Mokrzycka K, Janolis S. Wpływ edukacji przedporodowej na przebieg ciąży, porodu i wczesne macierzyństwo. Medycyna Ogólna i Nauki o Zdrowiu, 2016; 4: 264-269.

16. Mazurkiewicz B, Wietrzyńska A, Dmoch-Gajzlerska E. Decyzja o porodzie rodzinnym, motywy, uwarunkowania. Zdrowie i Dobrostan 2014; 3: 101-102.

17. Ćwiek D. Ocena wpływu edukacji w Szkołach Rodzenia na przebieg ciąży, porodu i połogu oraz opiekę nad noworodkiem. Roczniki Pomorskiej Akademii Medycznej w Szczecinie 2006; 1: 79-90.

18. Modrzejewska E, Torbe A, Ćwiek D. Opinie położnej na temat udziału partnera w porodzie. Położna, Nauka i Profilaktyka 2015; 4: 8-13.

19. Łapko M. Dojrzeć do macierzyństwa i ojcostwa. Magazyn Pielęgniarki i Położnej 2007; 11: 39.

20. Olejniczka D, Krakowiak K. Ocena potrzeby edukacji zdrowotnej kobiet w ciąży w zakresie stylu życia i karmienia piersią. Nowa Pediatria 2013; 3: 97-99.

21. Wolbiś M, Krychowska-Ćwikła A. Poród rodzinny w oczach ojca. Położna, Nauka i Praktyka 2012; 2: 30-36.

22. Żelazko K, Szlączka A, Pałczyńska M, Jaros A. Ocena przygotowania ciężarnej do porodu i macierzyństwa przez Szkołę Rodzenia. Współczesne Pielęgniarstwa i Ochrona zdrowia 2016; 2: 52-54.

23. Kołomyjec P, Suchocki S, Kędra-Rakoczy M. Wykształcenie i zachowanie prozdrowotne ciężarnych biorących udział w zajęciach Szkoły Rodzenia oraz ich wpływ na przebieg porodu i stan noworodka 2007; 3: 57-60.

24. Kamińska J, Mazurek M, Naworska B, Caus J, Kamiński B. Edukacja rodzinna Zdrowie Publiczne 2002; 112.

Artykuł przyjęty do redakcji: 19. 10. 2018.

Artykuł przyjęty do publikacji: 14.01.2019.

Źródło finansowania: Praca nie jest finansowana z żadnego źródła. Konflikt interesów: Autorzy deklarują brak konfliktu interesów.

\section{Adres do korespondencji:}

Katarzyna Plagens-Rotman

ul. Jackowskiego 41

60-512 Poznań

tel. 61 854-72-25

e-mail: rotman@ump.edu.pl

Katedra Zdrowia Matki i Dziecka, Wydział Nauk o Zdrowiu, Uniwersytet Medyczny im. Karola Marcinkowskiego w Poznaniu 